\title{
The Role of BRI Bank Medan Perjuangan Unit for Customer's Households, Indonesia
}

\author{
T. Enita Rosmika ${ }^{1}$, Amrin Mulia ${ }^{2}$, Putra Chairy ${ }^{3}$ \\ ${ }^{1,3}$ Universitas Amir Hamzah, Medan, Indonesia \\ ${ }^{2}$ Universitas Medan Area, Medan, Indonesia \\ putrachairy@gmail.com
}

\begin{abstract}
This study aims is to finds out how the role of BRI Bank in Medan Perjuangan unit for customer's households. This type of research that will be used in this study is the correlation method, which describes systematically about the influence of the KUR government program channeled by PT. BRI (Persero) Tbk. The result of this study the results of the 30 sample / debtor research, it can be concluded that the debtor feels an increase in living standards starting from increased production turnover, sales value, total profits, number of employees, and business assets after borrowing from BRI Bank Medan Perjuangan Unit. With the increase in the customer's business after making a loan to BRI Medan Perjuangan, it can be said that the loan received is well used for the business of the debtors and thus the credit assistance provided by the BRI Perjuangan Unit can be said to be effective in developing micro and small businesses.
\end{abstract}

Keywords: BRI Bank; customer households.

\section{Introduction}

The economy is a very important sector and is one of the focuses of the government in making various policies to achieve prosperity. So important is this economic sector that in every policy making must consider all aspects that may affect both positive and negative. The economy in Indonesia currently uses a populist economic system where the economic system is based on the strength of the people's economy, where the community holds an active role in economic activities, while the government creates a healthy climate for the growth and development of the business world.

Therefore, the government should pay attention to the sustainability of the activities of the Micro, Small and Medium Enterprises (UMKM). One of the ways that can be done by the government to help the Micro, Small and Medium Enterprises (UMKM) is to provide People's Business Credit (KUR) funding. People's Business Credit (KUR) is provided only by certain banks appointed by the government, namely: Bank Rakyat Indonesia (BRI), Bank Negara Indonesia (BNI), Bank Mandiri, Bank Syariah Mandiri, Bank Tabungan Negara and Bank Bukopin. Distribution of guarantee patterns is focused on five trading business sectors.

People's Business Credit (KUR) is issued based on Presidential Instruction No. 6 of 2007 concerning the Policy for the Acceleration of Real Sector Development and Empowerment of the Micro, Small and Medium Sectors, specifically in the Sector of Financial Sector Reform. Through the People's Business Credit (KUR) program, the Government expects an acceleration or acceleration of the development of economic activities in the context of poverty reduction or reduction and expansion of employment opportunities. KUR disbursed funds are fully funded by bank funds with a maximum credit ceiling of Rp.500,000,000, - in collaboration with the Government. The People's Business Credit (KUR) program is a loan in the form of cash to the borrower with the aim of becoming capital for the borrower to open a new business. The People's Business Credit (KUR) is intended to help the economy of small business people by providing loans for businesses they have established. 
Upon the submission of the loan application, of course, it must follow various procedures set by the bank concerned. In addition, the applicant must know the rights and obligations that will arise from each party, namely the debtor and creditor with the existence of the People's Business Credit agreement (KUR), bearing in mind that everything can arise into a problem if there is not enough knowledge about the People's Business Credit (KUR).

At present many micro and small businesses have been established. The running of each of these efforts is inseparable from the cost and more precisely the cost of assistance. This is still the responsibility of the Government so that the People's Business Credit (KUR) is the most feasible program and provides assistance to these business actors. The receipt of the People's Business Credit funds (KUR) is obtained from the Bank as a disbursement of funds in accordance with the process and stages and one of the national banks that serve the granting of KUR is PT. Bank Rakyat Indonesia (Persero) Tbk.

The distribution of the People's Business Credit (KUR) fund has the hope of being able to help (UMKM). in developing their businesses and helping the country's economy as well. As we know that effectiveness means a situation or activity reaches the level as desired, or successful. Means that it is hoped that the distribution of the People's Business Credit funds can succeed in helping the Indonesian people who conduct (UMKM). and be effective in developing micro, small and medium businesses.

\section{Review of Literature}

\subsection{Bank}

The allocation of funds to the public is carried out by banks by carrying out various strategies so that the public wants to invest their funds in the form of deposits based on public trust in maintaining adequate liquidity and trying to achieve reasonable rehabilitation and be able to maintain customer financial secrets.

According to RI Law No. 10 of 1998 dated 10 November 1998 concerning banking, what is meant by banks is "business entities that collect funds from the public in the form of deposits and distribute them to the public in the form of credit or other forms in order to improve the lives of many people" (Kasmir, $2008: 25$ ).

Bank can simply be interpreted as "financial institutions whose main activity is to collect funds from the public and channel them back to the community and provide other bank services (Kasmir, 2004: 11). Furthermore, if viewed from the origin of the occurrence of the Bank, the notion of the bank is a table or place to exchange money.

From the description above it can be explained that the Bank is a company engaged in the financial sector, meaning that the banking business is always related to financial matters. So it can be concluded that the banking business covers three main activities, namely:

a. Raise funds

b. Channeling funds and

c. Providing other bank services.

\subsection{Credit}

In everyday life, the word credit is a familiar word for the community. Credit is not only known by people in urban areas but even in rural areas credit is very popular. The term credit comes from the Greek word credere which means trust; the intention is that if someone obtains credit it means they get trust. As for the lender means giving confidence to someone 
that the money lent is definitely back. Definition of credit according to Banking Law No. 10 of 1998 is "the provision of money or bills which can be equivalent, based on the agreement or loan agreement between the bank and another party that requires the borrower to pay off the money after a certain period of time with the provision of interest".

From the above understanding it can be explained that credit can be in the form of money or bills whose value is measured by money, for example banks finance loans for the purchase of a house or car. Then there is an agreement between the bank (the creditor) and the credit recipient customer (the debtor), with the credit agreement covered by the rights and obligations of each party including a period of time, jointly determined interest and sanctions if the debtor fails to promise the agreement made. In general, the types of credit can be seen from various aspects, including the following (Kasmir, 2008: 103).

a. In terms of usability

- Investment credit

This credit is usually used for business expansion purposes.

For example, to build factories or buy machines.

- Working capital credit

Used for the purpose of increasing production in its operations. For example, working capital loans are given to buy raw materials, pay employee salaries and others.

b. Viewed in terms of credit objectives

- Productive credit

Credit used to increase business or production or investment. This credit is given to produce goods and services.

- Consumer credit

Credit used for personal consumption. Example:

Credit for housing, personal car loans, and other consumer loans.

- Trade credit

Credit used for trading, usually to buy merchandise for which payment is expected from the sale of the merchandise. For example: export-import credit.

c. In terms of time period

- Short-term credit

Loans that have a period of less than 1 year or a maximum of one year and are usually used for working capital purposes. For example, for agriculture such as rice or secondary crops.

- Medium-term credit

The credit period ranges from 1 year to 3 years, usually for investment. For example, credit for agriculture such as oranges, or goat farming.

- Long-term credit

This is a credit whose repayment period is more than 3 years or 5 years. Usually for long-term investment. For example, rubber plantations, oil palm or housing loans.

d. In terms of guarantee

- Credit with collateral

Credit granted with a guarantee that can take the form of tangible or intangible goods. 
- Unsecured loans

Is a credit given without collateral for certain goods or people. This credit is given by looking at the business prospects and character as well as the loyalty or good name of the prospective debtor so far.

e. Viewed in terms of the business sector

- Agricultural credit This is a credit financed for the plantation or smallholder agriculture sector.

- Farm credit

In this case, for the short term for example chicken farms and for the long term for Example goats or cattle.

- Industrial credit Is a credit to finance small, medium or large industries.

- Mining credit This type of mining business financed by credit is usually in the long run. Example: gold, oil or tin mining.

- Educational credit

It is a credit given to build educational facilities and infrastructure or can also be in the form of credit for students.

- Professional credit

Provided to professionals such as lecturers, doctors, lawyers.

- Housing loans

Is a credit to finance the construction or purchase of housing.

- And other sectors.

\subsection{People's Business Credit (KUR)}

Credit comes from the word credere, which means trust, meaning that if someone obtains credit, it means they obtain trust. As for the lender means giving confidence to someone that the money lent is definitely back. The definition of "credit" according to the Banking Law Number 10 of 1998 is "provision of money or bills that can be likened to it, based on a loan agreement or agreement between the bank and another party that requires the borrower to repay the debt after a certain period of time with interest.

Credit transactions can occur or arise because there is a party who is borrowing money or goods to other parties that can cause a charge for creditors. Another thing that can cause credit transactions is the sale and purchase activities where the payment will be deferred in a certain period of time either in part or in whole. The above credit activities will technically bring credit to the creditor and bring debt to the debtor. Definition of credit according to Law No. 7 of 1992 concerning Banking is the provision of money or claims that can be equaled, based on the agreement of the loan agreement between the bank and another party that requires the borrowing party to pay off the debt after a certain period of time with the amount of interest, compensation or profit sharing. Credit programs that are mostly carried out by banks have almost the same goal, namely to provide opportunities for people or communities to open or start their own jobs that are useful to improve their economic situation. Lending is divided into lending by the bank itself and there are those who work with the Government.

People's Business Credit (KUR) is one type of credit formed from the results of cooperation with the government. This credit is given through banks as creditors or providers 
of funds for people who want to build their own businesses. Because it is part of the government work program, KUR disbursement is generally carried out by PT. Bank Rakyat Indonesia (Persero) Tbk. where this bank is a state-owned bank.

People's Business Credit (KUR) is a loan that is intended for borrowers who want to start their own businesses but are still on a micro, small and medium scale. PT. Bank Rakyat Indonesia (Persero) Tbk. itself has a commitment to help develop Micro, Small and Medium Enterprises (UMKM) and improve community welfare. One form of that commitment is the opening of credit for venture capital for Micro and Small Enterprises (UMKM) and cooperatives, called the People's Business Credit (KUR). The People's Business Credit (KUR) is an alternative for Micro, Small and Cooperative Enterprises to get venture capital. The obstacles that are often faced by micro, small and cooperative entrepreneurs are capital problems in developing their business.

KUR itself was first launched by President Susilo Bambang Yudhoyono on November 5, 2007. The purpose of KUR launching is to accelerate the development of the real sector and empowering (UMKM), to increase access to finance to (UMKM) and cooperatives and to reduce poverty and expand employment opportunities. Basically, KUR is working capital and investment credit specifically provided to productive business units through the credit guarantee program. Individuals, groups or cooperatives can access this program with a maximum credit of IDR 500,000,000.

The source of funds is the designated bank with a maximum interest rate of 16 percent per year. The percentage of credit guaranteed is 70 percent of the total loan allocation provided by the bank. The maximum loan period for working capital is 3 years and 5 years for investment. Nationally, KUR distribution is directed to the trade, restaurant and hotel sectors, which account for $55 \%$ of total KUR distribution, followed by distribution to the agricultural sector by $27 \%$ and other sectors by $9 \%$.

\section{Research Method}

This type of research that will be used in this study is the correlation method, which describes systematically about the influence of the KUR government program channeled by PT. BRI (Persero) Tbk. Medan Perjuangan in developing small and medium micro businesses. With this method, it is expected to obtain data and information needed in research, as stated by Singarimbun and Effendi (2005: 3) that, Correlation is an attempt to obtain and collect data and information from various individuals, both in part or in full using standardized patterns that are patterned and structured according to the need for data, as well as referring to research topics and problems.

The location of this research was conducted at PT. BRI (Persero) Tbk. Battlefield.

The technique of analysis data used is to use moment product correlation and then it is tested through the $t$ test and by calculating the termination.

\subsection{Product Moment Correlation Coefficient}

Correlation is used to determine the degree of operating costs to company profits.

The calculation method uses the following formula: 
$r_{X Y}=\frac{N \sum X Y-\left(\sum X\right)\left(\sum Y\right)}{\sqrt{\left[N \sum X^{2}-\left(\sum X\right)^{2}\left[N \sum Y^{2}-\left(\sum Y\right)^{2}\right]\right.}}$ (Arikunto, $\left.2011: 236\right)$.

Information:

$\mathrm{rXY}=$ correlation coefficient

$\mathrm{X}=$ free variable $(\mathrm{X})=\mathrm{KUR}$ program

$\mathrm{Y}=$ Dependent Variable $(\mathrm{Y})=$ Micro Business Development

$\mathrm{N}=$ Number of Samples

Then to find out whether the relationship of the KUR program to Micro Business Development is a significant relationship or not, it must be tested using the value of $r$ product moment that is attached at the end of this thesis. Under the condition:

If rxy <from the value of $r$ product moment then there is no influence between the independent variable and the dependent variable, and if $\mathrm{rxy}>$ from the value of $\mathrm{r}$ product moment then there is an influence between the independent variable and the dependent variable.

\subsection{Test t.}

Test formula $t$.

At the significant level and degrees of freedom $\mathrm{dk}=\mathrm{n}-2$, it can be seen testing the research hypothesis and seeing the significant independent variables and the dependent variable with the provisions:

$$
t=r \frac{\sqrt{n-2}}{\sqrt{1-r^{2}}}
$$

- If $t$ arithmetic $>t$ table, then there is a significant influence between $x$ and $y$

- If $\mathrm{t}$ arithmetic $<\mathrm{t}$ table, then there is no significant effect between $\mathrm{x}$ and $\mathrm{y}$.

The relationship is said to be significant at the $95 \%$ confidence level if: $t^{\text {test }}>t$ table or vice versa, the relationship is not significant if: $\mathrm{t}^{\text {test }}<\mathrm{t}^{\text {table. }}$

\subsection{Coefficient of Determination}

This technique is used to find out what percentage of the effect of independent variables on the dependent variable. The calculation is done by squaring the product moment coefficient ( $\mathrm{r}$ xy) and multiplied by $100 \%$ (one hundred percent).

$\mathrm{D}=(\mathrm{rXY})^{2} \mathrm{x} 100 \%$

Information:

$\mathrm{D}=$ coefficient of determination

${ }^{\mathrm{r}} \mathrm{XY}=$ Product moment correlation coefficient between $\mathrm{X}$ and $\mathrm{Y}$. 


\section{Discussion}

In this study the population includes all the customers of the People's Business Credit BRI Bank Perjuangan Unit Medan and respondents as a sample of 30 people. Based on information obtained from the questionnaire provided, respondents were classified into several groups based on the type of age, gender, occupation, and duration of credit collection.

Age indicates their age at the time of the study. The age characteristics of the respondents can be seen in the following table:

Table 1. Characteristics of Respondents by Age

\begin{tabular}{|l|l|l|}
\hline Information & Total & Percentage \\
\hline $22-30$ years & 4 & 13,33 \\
\hline $31-40$ years & 8 & 26,67 \\
\hline $31-40$ years & 8 & 26,67 \\
\hline$>50$ years & 10 & 33,33 \\
\hline Total & 30 & 100,00 \\
\hline
\end{tabular}

Source: Primary data processed

From the table above shows that the most number of respondents are aged over 50 years $(33.33 \%)$, then respondents with ages $31-40$ years $(26.67 \%)$ are as many as respondents aged between $41-50$ years $(26,67 \%)$, and finally respondents aged between 22-30 years $(13.33 \%)$.

\subsection{Gender}

Characteristics of respondents by sex can be seen in the table below:

Table 2. Characteristics of Respondents by Gender

\begin{tabular}{|l|l|l|l|}
\hline No & Information & Total & Percentage \\
\hline 1. & Female & 17 & 56,67 \\
\hline 2. & Male & 13 & 43,33 \\
\hline & Total & 30 & 100,00 \\
\hline
\end{tabular}

Source: Primary data processed

From the table above shows that the most number of respondents are women as many as 17 respondents (56.67\%) and Male respondents as many as 13 people or $43.33 \%$.

\subsection{Education}

Characteristics of respondents based on education can be seen in the table below:

Table 3. Characteristics of Respondents Based on Education

\begin{tabular}{|l|l|l|l|}
\hline No & Information & Total & Percentage \\
\hline 1. & Primary school & 2 & 6,67 \\
\hline 2. & Junior High School & 4 & 13,33 \\
\hline 3. & Senior High School & 18 & 60,00 \\
\hline 4. & Academic & 6 & 20,00 \\
\hline & Total & 30 & 100,00 \\
\hline
\end{tabular}

Source: Primary data processed 
The table above shows that the highest number of respondents has a high school level of 18 respondents (60\%), Academic 6 respondents (20\%), SMP 4 respondents (13.33\%), and elementary school 2 respondents $(6.67 \%)$.

\subsection{Scale of customer business}

Of the 30 customers studied, these members are more engaged in micro and small business types, because one of the main objectives of the Medan Perjuangan Unit is to help traders, farmers and others who find it difficult to find a place to trade and capital and are difficult to get loans, but this does not cover up for medium and large entrepreneurs to borrow from BRI. Based on the 30 samples, it can be seen in the table below that the percentage of the number of micro and small entrepreneurs in the BRI BRI Perjuangan Unit is seen:

Table 4. Percentage of Micro and Small Enterprises in Medan Perjuangan Unit

\begin{tabular}{|l|l|l|l|}
\hline No. & Information & Total & Percentage \\
\hline 1. & Micro business & 24 & 80,00 \\
\hline 2. & Small business & 6 & 20,00 \\
\hline & & 30 & 100,00 \\
\hline
\end{tabular}

Source: Primary data processed

The table above explains that from the 30 samples obtained, there were $80 \%$ of the data or as many as 24 customers in the micro-scale business and entrepreneurs in the small scale of $20 \%$ or 6 members. The level of scale of this business is measured by the large number of workers in each business both from the number of permanent and casual or daily workers as well as by various types of products sold by traders to consumers. The measure for the number of workforce where if the workforce consists of 1 to 4 people, then the workforce is micro and for the size of the workforce of 4 to 19 people is included in the scale of small businesses.

a. Legal entity

The existence of the legal entity also needs to be owned by each customer so that the business run by the customer can be managed regularly and the objectives can be achieved. However, not all customers have a legal entity, because of the 30 samples there are also entrepreneurs who do not have a legal entity, as shown in the table below.

Table 5. Percentage of Entrepreneurs by Legal Entity

\begin{tabular}{|l|l|l|l|}
\hline No. & Legal entity & Total & Percentage \\
\hline 1. & Individual & 6 & 20,00 \\
\hline 2. & There is no legal entity & 24 & 80,00 \\
\hline & & 30 & 100,00 \\
\hline
\end{tabular}

Source: Primary data processed

Based on the picture above from 30 samples representing several customers, there are still $80 \%$ of members who do not have a legal entity for their business and there are as many as $20 \%$ of customers who already have a legal entity. Although the members' legal entities are only limited to individual legal entities and not to legal entities such as firms, foundations, 
limited liability companies and so forth. This is because these customers are still in the form of micro and small businesses where their business activities still have capital and management that are handled by one person who acts as a whole. Thorough means that this person moves as a manager, administrator, and supervisor, while others only act as employees.

b. Bookkeeping System

Bookkeeping system for customers is still simple, where customers do not really understand how to manage bookkeeping that is good for their business so that the business they live can be seen progress and can make good planning for future business progress. As in the above aspects, the following aspects also use 30 customer samples. The types of bookkeeping that are generally carried out by entrepreneurs are in the following table:

Table 6. Types of Customer Member Bookkeeping

\begin{tabular}{|l|l|l|l|}
\hline No. & Bookkeeping Type & Number of Members & Percentage \\
\hline 1. & $\begin{array}{l}\text { Record of Daily Revenue } \\
\text { and Expenditures }\end{array}$ & 25 & 83,33 \\
\hline 2. & Inventory note & 12 & 40,00 \\
\hline 3. & Profit and loss & 4 & 13,33 \\
\hline
\end{tabular}

Source: Primary data processed

If seen from the results of the questionnaire shows that the customers do indeed have a total bookkeeping but still have a simple bookkeeping and the books have not reached the type of bookkeeping balance sheet, cash flow and so on. One of the factors is because customers still have low knowledge about the processing of financial books and good business planning, here also need counseling from both banks and local governments to inform entrepreneurs how to process financial accounting books that are good.

In general, one of the obstacles for micro and small entrepreneurs is regarding funding sources. Sources of financing are usually very closely related to increased income or also called increased turnover. Every person or group member who is engaged in economic business, especially trade, always tries to find the maximum possible income. In the world of commerce where to obtain maximum income, it is necessary to have adequate costs or capital as well. But for micro and small entrepreneurs to get an easy and low-cost source of financing is very difficult. So generally these micro and small entrepreneurs are more trusting in their own capital or financing sources compared to capital obtained from outside, but if the source of funding is deficient then the owners of micro and small businesses will make and consider lending to external parties, such as the BRI Bank Unit Battlefield.

So this is where the presence and role of the BRI Bank Unit Sei Medan Perjuangan provide enormous benefits to help micro and small entrepreneurs. This is also felt by micro and small traders who are also customers at the BRI Bank Medan Perjuangan Unit. Clients acknowledge that the existence of cooperatives is very helpful to support the business progress of entrepreneurs. The BRI Bank Medan Perjuangan Unit has a different role from other institutions because for various reasons customers above the BRI Unit Medan Perjuangan Unit are more in favor of entrepreneurs with limited capital. A statement stating that indeed BRI Bank Unit Medan Perjuangan is more dominant as an institution to conduct loans for micro and small entrepreneurs. From the questions asked to 30 customers, it was 
found that the customer said that the BRI Bank Unit Medan Perjuangan was very instrumental in the development of MSE businesses, while other institutions still lacked an active role in the progress of micro and small entrepreneurs.

BRI Bank Perjuangan Unit in UMK empowerment can also be seen from the business life after getting a loan and this can be seen from research on customers of BRI Bank Perjuangan Unit, as shown in the table below.

Table 7. Customer Business Development after getting a loan BRI Bank Unit Medan

Perjuangan

\begin{tabular}{|c|c|c|c|c|c|c|c|}
\hline \multirow[b]{2}{*}{ No. } & \multirow[b]{2}{*}{ Question } & \multicolumn{2}{|l|}{ Stable } & \multicolumn{2}{|l|}{ Increase } & \multicolumn{2}{|c|}{ Very Increased } \\
\hline & & $\begin{array}{l}\text { Number } \\
\text { of People }\end{array}$ & $\%$ & $\begin{array}{l}\text { Number } \\
\text { of People }\end{array}$ & $\%$ & $\begin{array}{l}\text { Number } \\
\text { of People }\end{array}$ & $\%$ \\
\hline 1. & $\begin{array}{l}\text { Production } \\
\text { Turnover }\end{array}$ & - & - & 22 & 88,00 & 3 & 12,00 \\
\hline 2. & Sales Value & - & - & 22 & 88,00 & 3 & 12,00 \\
\hline 3. & $\begin{array}{l}\text { Sales } \\
\text { Territories }\end{array}$ & - & - & 22 & 81,48 & 5 & 18,52 \\
\hline 4. & Total Profit & 15 & 60,00 & 10 & 40,00 & - & - \\
\hline 5. & $\begin{array}{l}\text { Number of } \\
\text { employees }\end{array}$ & 10 & 41,67 & 12 & 50,00 & 2 & 8,33 \\
\hline 6. & $\begin{array}{l}\text { Company } \\
\text { Assets }\end{array}$ & - & - & 15 & 88,24 & 2 & 11,76 \\
\hline
\end{tabular}

Source: Primary data processed

From the results of the above research it can be explained that the development of the life of BRI Bank Medan Perjuangan Unit customers who are also engaged in micro and small businesses, namely on production turnover, sales value, sales area, total profits, number of employees and company assets which all have increased. This means that the role of the BRI Bank Unit Medan Perjuangan in the form of counseling given to micro and small businesses has gone well.

From the questions in the table where production turnover from micro and small entrepreneurs or members is the most important thing to assess the business has increased or setbacks, because production turnover is the starting point to see an increase in member shares. From the table above it can be seen in detail with as much as $88 \%$ increased production turnover and $12 \%$ greatly increased production turnover this indicates the difference that leads to a positive direction regarding business development between before making loans and after making loans and this also means that the existence BRI Bank Medan Perjuangan is very supportive in micro and small businesses in the surrounding area.

In addition to seeing the development of the customer's household, where on the one hand we cannot only assess the progress of the micro and small entrepreneurs' progress only through the development of their businesses, but for the development of their households also needs to be reviewed. To find out the development of the household, it is in the table below: 
Table 8. Development of the Household Life of the Customer after Conducted Loans from BRI Bank Unit Medan Perjuangan

\begin{tabular}{|l|l|l|l|l|l|l|l|}
\hline \multirow{2}{*}{ No. } & \multirow{2}{*}{ Question } & \multicolumn{2}{|c|}{ Stable } & \multicolumn{2}{l|}{ Improve } & \multicolumn{2}{l|}{ Very good } \\
\cline { 3 - 8 } & & $\begin{array}{l}\text { Number } \\
\text { of People }\end{array}$ & $\boldsymbol{\%}$ & $\begin{array}{l}\text { Number } \\
\text { of People }\end{array}$ & $\%$ & $\begin{array}{l}\text { Number } \\
\text { of People }\end{array}$ & $\%$ \\
\hline 1. & Home & 17 & 56,67 & 10 & 33,33 & 3 & 10,00 \\
\hline 2. & Vehicle & 7 & 23,33 & 19 & 63,33 & 4 & 13,33 \\
\hline 3. & Television & 8 & 26,67 & 17 & 56,67 & 5 & 16,67 \\
\hline 4. & Radio/Tape & 9 & 30,00 & 18 & 60,00 & 3 & 10,00 \\
\hline 5. & $\begin{array}{l}\text { RT } \\
\text { furniture }\end{array}$ & - & - & 25 & 83,33 & 5 & 16,67 \\
\hline 6. & RT income & - & - & 22 & 73,33 & 8 & 26,67 \\
\hline 7. & RT Savings & - & - & 19 & 63,33 & 11 & 36,67 \\
\hline
\end{tabular}

Source: Primary data processed

The table above shows that it is not much different from the development of its business, because the development of households of micro and small entrepreneurs who become customers has also increased. Starting from the house to household savings has improved, where previously members did not have a house or are still renting now members generally have their own homes, as well as others. Just as in business development where the measurement of progress is the turnover of production, then the development of households as a benchmark of progress can be seen in terms of household income.

From the table above in detail it can be seen that the household income of the customers has increased and this percentage is not far from the increase in production turnover. If this progress continues then it is possible, if the existing micro and small businesses can develop into large businesses.

\section{Conclusion}

From the results of the 30 sample / debtor research, it can be concluded that the debtor feels an increase in living standards starting from increased production turnover, sales value, total profits, number of employees, and business assets after borrowing from BRI Bank Medan Perjuangan Unit. With the increase in the customer's business after making a loan to BRI Medan Perjuangan, it can be said that the loan received is well used for the business of the debtors and thus the credit assistance provided by the BRI Perjuangan Unit can be said to be effective in developing micro and small businesses. 


\section{References}

Arikunto, S. (1996). Manajemen Penelitian. PT Rineka Cipta: Jakarta. , (1998). Prosedur Penelitian Suatu Pendekatan Praktek. PT Rineka Cipta: Jakarta.

B. A Nugroho. (2005). Strategi Jitu Memilih Metode Statistik Penelitian dengan SPSS. Yogyakarta: ANDI.

Barnard, I, Chester, (1992). Organisasi dan manajemen, Struktur, Perilaku dan Proses. Gramedia: Jakarta.

http://usaha-umkm.blog.com/tag/ciri-ciri-umkm, Konsultan Sektor Riil \& UMKM Indonesia. Supranto, J, 2001. Statistik Teori dan Aplikasi. Cetakan Kedua. Penerbit Erlangga: Jakarta. Umar, H. (2009). Metode Penelitian untuk Sripsi dan Tesis Bisnis. Edisi 2. Rajawali Pers: Jakarta.

www.google.com, Pemberdayaan Usaha Mikro dan Kecil (UMK).

www.yahoo.com, Kebijakan Percepatan Pengembangan dan Pemberdayaan Usaha Mikro dan Kecil (UMK).

www.bri.co.id. 